\title{
The Effect of Intellectual Capital on Innovation: A Case Study of an Institute for Advanced Studies in Basic Sciences Located in the Science and Technology Park of Zanjan
}

Mahya Maboudi ${ }^{1}$, Mohammad Hassan Mobaraki ${ }^{2}$, Jalil Khavandkar ${ }^{3}$ and Hossein Moghimi Esfandabadi*

${ }^{1}$ Department of Entrepreneurship Management, University of Tehran, 16th St. North Kargar Ave., Tehran, Iran

${ }^{2}$ Department of Corporate Entrepreneurship, University of Tehran, 16th St. North Kargar Ave., Tehran, Iran

${ }^{3}$ Visiting Professor of Entrepreneurship at Tehran University, Founder and Director of Zanjan Science and Technology Park-IASBS, Zanjan, Iran

${ }^{4}$ Department of Social Sciences, University of Tehran, North Kargar Ave., Tehran, Iran

\begin{abstract}
The present research aims to investigate the effect of intellectual capital on innovation in Zanjan Science and Technology Park (STP) during 2013. This study was conducted based on the quality-correlation method. The research questionnaire was distributed between employees who worked for any of the firms inside the STP. In general, 220 employees work in Zanjan Science and Technology Park, 139 of whom were selected using the Cochran's formula to reply to the questionnaire. Structural equation modeling was used to analyze the data. The results of the correlation test revealed a significant positive relationship between intellectual capital and innovation. The elements of structural capital and human capital did not indicate any significant relationship with innovation. However, it was found that the elements of intellectual capital (i.e. human capital, structural capital, and relational capital) can be used as predictors of innovation in our case study.
\end{abstract}

Keywords: Intellectual capital; Innovation; Structural capital; Human capital; Relational capital; Zanjan Science and Technology Park

\section{Introduction}

Today, with the global trend toward knowledge-based economies, firms need embrace innovation in order to survive and grow in intense competition. Innovation seems to be a competitive advantage which encourages organizational growth and acts as a growth engine enabling firms to show higher efficiency in the global economy [1]. Liao and Wu define innovation as a new product or service, a new production process technology, a new structure or administrative system, or a new plan or program pertaining to organizational members. Therefore, firms should seek the right culture, structure, systems, and processes which facilitate innovation and increase their innovative capacity [1].

Implementation of innovation depends on the capital changes in an organization. Capital was modified from its traditional economic basis to first comprise human capital (HC), and then social capital, and finally intellectual capital (IC) implications. These changes in the forms of capital have attracted the attention of a number of scholars as a key factor in fostering innovation [2-5].

This paper's definition of innovation outlines the intermediating role of relational capital (RC) and $\mathrm{HC}$ between structural capital (SC) and innovation. Based on the literature, innovation is a creative action which is necessary for creating SC. SC refers to organizational culture, organizational processes, organizational learning [6] which leads to HC and RC. HC refers to individual knowledge, skills, abilities, and experiences of the employees in an organization [7]. RC refers to customers and relationships between stakeholders.

Due to the flexible structure of STP, SC could lead STP's firms toward innovative environments via their internal and external communications (i.e. RC) and also via benefiting from employees knowledge, ability and experiences (HC).

\section{Theoretical Framework}

In this section, we will first define the variables of the study and then review the literature about the effect of IC on innovation.

\section{Intellectual capital}

Today, IC has become one of the main instruments for attaining more productivity and success among organizations. Therefore, organizations need to foster this type of capital [8]. There is no consensus regarding the definition of IC, hence the different definitions based on the researchers' personal points of view and various conceptual models.

All categories of IC commonly focus on the three dimensions of HC, SC and RC [9]. For Example Edvinson and Malone [10] have pointed out to three dimensions of IC as including: SC, HC, and RC (Table 1).

Finally, it should be noted that the three types of capital (i.e. SC, HC, and RC) can affect the performance and success of an organization. Therefore, the existence of a relationship between them is of great importance and organizations shouldn't focus on improving one capital only.

\section{Literature Review}

According to the literature, IC is considered as one of the most important sources of competitive advantage $[6,11,12]$. Evidence shows that IC has a positive impact on organizational innovation $[2,4,13]$

*Corresponding author: Hossein Moghimi Esfandabadi, Graduate of Sociology, Faculty of Social Sciences, University of Tehran, North Kargar Ave., Tehran, Iran E-mail: Hme.moghimi30@gmail.com

Recieved June 04, 2015; Accepted August 20, 2015; Published September 10 2015

Citation: Maboudi M, Mobaraki MH, Khavandkar J, Esfandabadi HM (2015) The Effect of Intellectual Capital on Innovation: A Case Study of an Institute for Advanced Studies in Basic Sciences Located in the Science and Technology Park of Zanjan. J Entrepren Organiz Manag 4: 148. doi:10.4172/2169-026X.1000148

Copyright: (c) 2015 Maboudi M, et al. This is an open-access article distributed under the terms of the Creative Commons Attribution License, which permits unrestricted use, distribution, and reproduction in any medium, provided the original author and source are credited. 
Citation: Maboudi M, Mobaraki MH, Khavandkar J, Esfandabadi HM (2015) The Effect of Intellectual Capital on Innovation: A Case Study of an Institute for Advanced Studies in Basic Sciences Located in the Science and Technology Park of Zanjan. J Entrepren Organiz Manag 4: 148. doi:10.4172/2169-026X.1000148

Page 2 of 5

\begin{tabular}{|l|l|l|}
\hline Elements & Definitions \\
\hline SC & $\begin{array}{l}\text { SC refers to structures and processes within an organization which employees use them to employ their knowledge and } \\
\text { skills. }\end{array}$ \\
\hline $\begin{array}{l}\text { This capital includes structures as well as mechanisms which their basic role is to support the employees to achieve to } \\
\text { an optimum intellectual performance and ultimately an optimum performance in the business. }\end{array}$ & $\begin{array}{l}\text { Alam Tabriz et al.[8] } \\
\text { Edvinson and Malone argued that SC supports and increases the staff's performance but it also remains even after the } \\
\text { time an employee leaves the organization. }\end{array}$ \\
\hline HC & $\begin{array}{l}\text { HC has been defined as the set of knowledge, skills, abilities, and experiences of the employees in an organization that } \\
\text { help with creating value and solving business problems. }\end{array}$ \\
\hline $\begin{array}{l}\text { HC is considered as the most important asset of an organization, an essential resource for creativity, as well as, } \\
\text { innovation, and also a competitive advantage for the organization. }\end{array}$ & \begin{tabular}{l} 
Organizations which benefit from a high share of HC, act more innovatively and solve their problem faster. \\
\hline RC
\end{tabular} & $\begin{array}{l}\text { RC refers to all the knowledge within the relationships in an organization with its external environment including } \\
\text { customers and partners. }\end{array}$ \\
\hline $\begin{array}{l}\text { RC is considered as an essential component of intellectual capital, referring to an embedded value in marketing } \\
\text { channels and relations though which organizations lead their business, and consider their customers as the most } \\
\text { important part of that capital. }\end{array}$ \\
\hline
\end{tabular}

Table 1: Definitions of structural capital, human capital and relational capital.

Subramaniam [13] argue that human, organizational, and social capital as well as the interactive relations among individuals affects both incremental and radical innovation. It has been shown; on the one hand, that SC has a positive effect on innovative capacity. On the other hand, HC, which is in interaction with social capital, has a positive effect on innovation.

In a study about the effect of IC on organizational innovative propensity, Aldujaili maintains that the main hypothesis of the study was rejected, and just the effect of the SC and HC on organizational innovation was confirmed. RC also had no significant effect on innovation. In fact, Iraqi manufacturing firms showed a weak relationship with suppliers, customers, and competitors. Conversely, Delgado [4] investigated the effect of HC, technological, relational and social capital on incremental and radical innovation and found that intellectual properties directly affect innovation; additionally, $\mathrm{HC}$ has a mediating role in the relationship between $\mathrm{RC}$ and radical innovations.

Zerenler et al. [5] also considered the three indicators of SC, HC, and $\mathrm{RC}$ regarding IC and found that all the three dimensions of IC have a positive and strong relationship with innovative performance. $\mathrm{RC}$ had a more significant effect on innovative performance, while the two other dimensions of HC and SC had a less significant effect.

In general, it seems that most studies in the IC literature focus on the three indicators of $\mathrm{HC}, \mathrm{SC}$, and RC [14]. As the first indicator, HC has been defined as the set of knowledge, skills, abilities, and experiences of the employees that help with creating value and solving business problems and it is considered a source of innovation [15].

SC refers to structures and processes within an organization which employees can use in order to employ their knowledge and skills [3]. $\mathrm{RC}$, the third indicator of IC, refers to relations with key beneficiaries including staff, customers, stakeholders, and other individuals who benefit from financial promotions [16].

\section{Conceptual framework}

Innovation in an organization does not occur because of shortage; rather, the organizational structure prepares the conditions as a context. The organizational structure is the indicator of the relationships between different units within an organization and their flexibility. Therefore, innovation resources include all organizational structures and strategies, customer demands, and interaction with beneficiaries. The STPs' structure also requires the organization to be innovative with

\section{the products and services which it offers.}

According to Russelle, the organizational structure has been considered as the most effective factor in relation to innovation, and it has been argued that organizational structural prepares the context for innovation. This capital is obtained through mediating human and relational capitals.

Bounfour introduced the IC-dVAL approach and recognized four dimensions of SC, HC, market capital, and innovation, and incorporated these four dimensions in an integrated framework, and then suggested a relationship between entries (resources), processes, intangible assets, and firm's innovative performance. Therefore, culture creates innovation, and resources can continue just when RC and $\mathrm{HC}$ exist in an organization and these capitals result in innovative behaviors in the organization.

Parsons also introduced the theory of structural-functionalism and argued that every system includes some structures and each structure has different functions. Parsons recognized culture as a determinant in a society which any kind of change in it leads to a change in other sections of the society. Since a society is built and continues to live based on norms, values and beliefs, culture is the source of all cultural changes. As regards the relationship between $\mathrm{HC}$ and innovation based on Longo's model (2007), HC is first the foundation of IC; second, a constant source of innovation renewal for the organization; third, is able to understand the issues; and fourth, can benefit from the experiences to create value. With this respect, in their classification of IC, Edvinson and Malone [10] has introduced the SC as a supporting factor for HC.

In a study of the effect of RC and innovation among STPs' firms, Palmberg and Hult $[17,18]$ argued not only does innovation involve technological matters, but also other variables which are recognized as sources of innovation such as customer demand, market, and collaboration with customers. Technological change is not likely to provide customers with instant value, however, new technologies can attack an established market and therefore be considered as a source of innovation. Firms need to collect data about customer needs before they seek new ways to fulfil them sine it is the customers who enable firms to create value.

Hult et al. [18] found that entrepreneurial market orientation and learning are key predicting variables for innovation. It should be noted that three components of IC have intra-correlation. The interactive 
Citation: Maboudi M, Mobaraki MH, Khavandkar J, Esfandabadi HM (2015) The Effect of Intellectual Capital on Innovation: A Case Study of an Institute for Advanced Studies in Basic Sciences Located in the Science and Technology Park of Zanjan. J Entrepren Organiz Manag 4: 148. doi:10.4172/2169-026X.1000148

Page 3 of 5

relationships between the three components of IC could be a part of the positive effect of $\mathrm{HC}$ on SC, because SC can result in distribution of the individuals' technical knowledge across groups. SC also has a positive effect on RC. In fact, RC is the knowledge which defines the relations of an organization with customers and external stakeholders. As a part of the RC mix, HC plays a role in all the administrative activities in an organization [14]. RC has a positive influence on $\mathrm{HC}$ because $\mathrm{RC}$ can increase both HC and SC as it refers to an organization's ability to establish positive interaction with external stakeholders, gain their perceptions of the organization, and exchange information with customers. The conceptual model of the research is presented below which shows the relationship between IC (i.e. HC, SC and RC) with innovation (Figure 1).

\section{Research Methodology}

This research is falls into the category of empirical studies and employs the qualitative correlation method. The questionnaire was distributed between the firms' employees who worked for any of the firms inside the STP. In general, 220 employees work in Zanjan STP of whom 139 individuals were selected according to the Cochran's formula to reply to the questionnaire. The questionnaire was prepared in the form of statistical samples considered for this study (including all employees working in the park firms). Structural equation modeling was used to analyze the data. The results of the correlation test revealed a significant positive relationship between IC and innovation; and the effect of IC on innovation was identified after analysis of the collected data. Reliability was measured based on the two criteria of Cronbach's alpha and the composite reliability (CR). Validity was also determined by measuring the convergent and divergent validity. Convergent validity determines whether the correlation between a construct and the questions related to that construct is sufficient, while divergent validity compares the correlation between a construct and the questions related to that construct; and the correlation of that construct with other constructs. Table 2 shows these values.

\section{Results}

\section{Descriptive statistics based on demographics}

The descriptive statistics of the study show that $64 \%$ of the participants were male and $36 \%$ were female. Regarding education, most participants ( 65 per cent) had a bachelor's degree (BA), while the frequency of individuals who had a $\mathrm{PhD}$ degree was zero. In terms of work experience, the highest frequency (60 per cent) was related to the

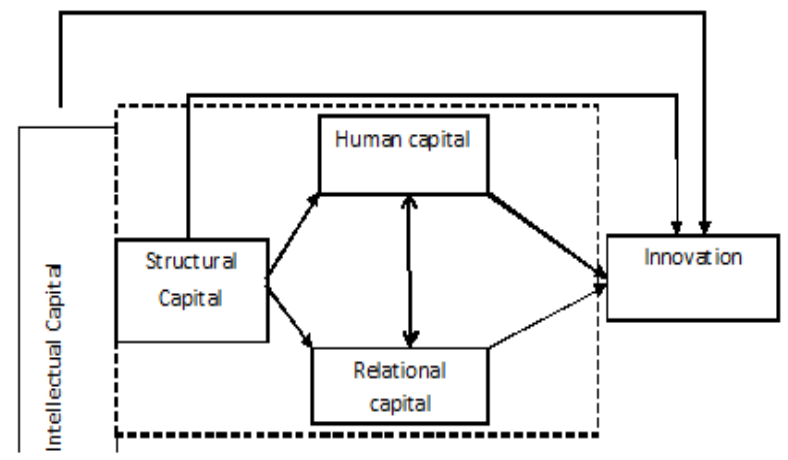

Figure 1: Conceptual framework adapted from Bounfour, Longo [15] and Palmberg [17].

\begin{tabular}{|l|c|c|c|c|c|c|}
\hline Measure & $\begin{array}{c}\text { Cronbach's } \\
\text { alpha }\end{array}$ & $\begin{array}{c}\text { Composite } \\
\text { reliability }\end{array}$ & $\begin{array}{c}\text { Convergent } \\
\text { validity }\end{array}$ & $\begin{array}{c}\text { Divergent } \\
\text { validity }\end{array}$ & $\begin{array}{c}\text { Number of } \\
\text { items }\end{array}$ & Scale \\
\hline Criterion & Up to $\mathbf{0 . 7}$ & Up to $\mathbf{0 . 7}$ & Up to $\mathbf{0 . 4}$ & - & - & - \\
\hline SC & 0.75 & 0.83 & 0.50 & 0.711 & 5 & Interval \\
\hline HC & 0.70 & 0.74 & 0.40 & 0.581 & 6 & Interval \\
\hline RC & 0.73 & 0.81 & 0.42 & 0.651 & 6 & Interval \\
\hline Innovation & 0.71 & 0.73 & 0.37 & 0.565 & 6 & Interval \\
\hline
\end{tabular}

Table 2: The values for convergent validity, divergent validity, composite reliability, Cronbach's alpha.

\begin{tabular}{|l|c|c|c|c|c|}
\hline Indicator & Frequency & Lower limit & Upper limit & Mean & $\begin{array}{c}\text { Standard } \\
\text { deviation }\end{array}$ \\
\hline IC & 103 & 13.73 & 45.63 & 25.64 & 6.14 \\
\hline $\mathrm{SC}$ & 103 & 4.2 & 17.4 & 8.66 & 2.97 \\
\hline $\mathrm{RC}$ & 103 & 3.33 & 24.67 & 11.88 & 3.46 \\
\hline HC & 103 & 6.17 & 20.33 & 10.86 & 2.78 \\
\hline Innovation & 103 & 0 & 16.67 & 9.07 & 2.81 \\
\hline
\end{tabular}

Table 3: Descriptive statistics based on the indicators of the study.

category of 'under 5 years'; and the lowest frequency was related to the category of 'between 16-20 years'.

\section{Descriptive statistics based on the indicators}

Based on the table above, the minimum and maximum score of the indicators are based on the individuals' scores in each pertinent indicator. For example, the minimum SC score of the individuals is 4.20 , whereas their maximum score is 17.20 . Based on the difference between the minimum and maximum scores, the standard deviation has been measured 2.97 for SC.

\section{Hypotheses test}

Simple linear regression was used to examine the linear relationships of the variables. The purpose of using regression is to measure the linear relationships of the indicators with the dependent variable (i.e. innovation)

As it can be seen in Table 3, according to the regression coefficients with values greater than 0.3 , the relationships between the variables are positive, however, with average or less than average strength. On the other hand, since the significance level is 0.000 , which is less than a $=0.01$, none of the hypotheses are rejected. In other words, the linear relationship between the variables is supported. As for the significance level of 0.026 , which is less than $\mathrm{a}=0.05$, the hypothesis for existence of a relationship between SC and innovation is rejected. The measurement models shown in Tables 4 and 5, Figures 2 and 3 explain the main and 5 sub-hypotheses.

\section{Defining the $6^{\text {th }}$ sub-hypothesis through using Pearson correlation coefficient}

How is the correlation between RC and HC in Zanjan University STP firms?

Based on the test results above and the correlation coefficient in the significance level of 0.01 , there is a significant correlation between HC and RC (Table 6).

\section{Conclusion and Discussion}

A study of characteristics and factors that affect organizational innovation demonstrates that with technological growth, more 
Citation: Maboudi M, Mobaraki MH, Khavandkar J, Esfandabadi HM (2015) The Effect of Intellectual Capital on Innovation: A Case Study of an Institute for Advanced Studies in Basic Sciences Located in the Science and Technology Park of Zanjan. J Entrepren Organiz Manag 4: 148. doi:10.4172/2169-026X.1000148

Page 4 of 5

\begin{tabular}{|l|c|c|}
\hline Indicators & Regression coefficient & Sig. level \\
\hline IC on innovation & 0.422 & 0.000 \\
\hline SC on HC & 0.548 & 0.000 \\
\hline SC on RC & 0.491 & 0.000 \\
\hline HC on innovation & 0.378 & 0.000 \\
\hline RC on innovation & 0.381 & 0.000 \\
\hline SC on innovation & 0.220 & 0.026 \\
\hline
\end{tabular}

Table 4: The linear relation of IC dimensions with innovation.

\begin{tabular}{|l|c|c|c|c|}
\hline Results & $\begin{array}{c}\text { Coefficient } \\
\text { (B) }\end{array}$ & $\begin{array}{c}\text { Sig level } \\
\text { (t) }\end{array}$ & Effect & Hypotheses \\
\hline $\begin{array}{l}\text { Positive and } \\
\text { significant effect }\end{array}$ & 0.469 & 5.413 & $\begin{array}{c}\text { The effect of IC on } \\
\text { innovation }\end{array}$ & Main hypothesis \\
\hline $\begin{array}{l}\text { Positive and } \\
\text { significant effect }\end{array}$ & 0.582 & 8.227 & $\begin{array}{c}\text { The effect of SC } \\
\text { on HC }\end{array}$ & Sub-hypothesis 1 \\
\hline $\begin{array}{l}\text { Positive and } \\
\text { significant effect }\end{array}$ & 0.594 & 10.348 & $\begin{array}{c}\text { The effect of SC } \\
\text { on RC }\end{array}$ & Sub-hypothesis 2 \\
\hline No effect & 0.056 & 0.394 & $\begin{array}{c}\text { The effect of HC } \\
\text { on innovation }\end{array}$ & Sub-hypothesis 3 \\
\hline $\begin{array}{l}\text { Positive and } \\
\text { significant effect }\end{array}$ & 0.517 & 3.732 & $\begin{array}{c}\text { The effect of RC } \\
\text { on innovation }\end{array}$ & Sub-hypothesis 4 \\
\hline No effect & -0.001 & -0.009 & $\begin{array}{c}\text { The effect of SC } \\
\text { on innovation }\end{array}$ & Sub-hypothesis 5 \\
\hline
\end{tabular}

Table 5: The hypotheses test results.

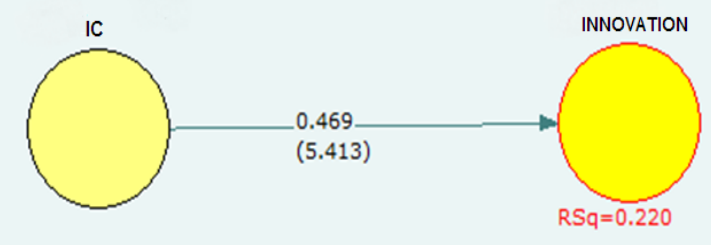

Figure 2: Path analysis and significance level in the measurement model to explain the main hypothesis.

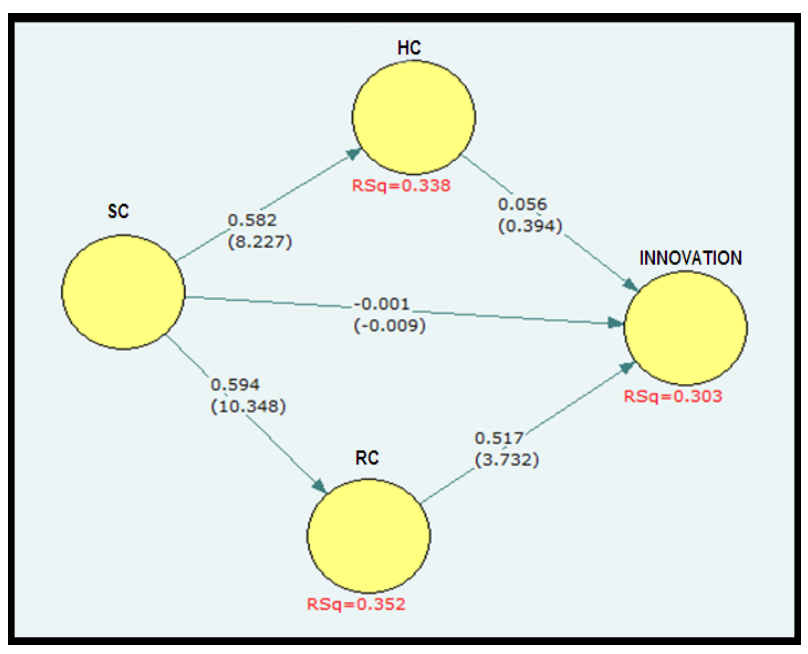

Figure 3: Path analysis and significance level in the measurement model to explain the 5 sub-hypotheses.

complex organizations, and organizational competition, the effect of innovation among managers, staff, researchers and experts in various disciplines has become more important. What helps organizations

\begin{tabular}{|r|c|c|}
\hline & $\mathrm{HC}$ & $\mathrm{RC}$ \\
\hline $\mathrm{HC}$ & 1 & $.545^{\star *}$ \\
\hline $\mathrm{RC}$ & $.545^{\star *}$ & 1 \\
\hline $0.01^{* *}$ sig level & & \\
\hline
\end{tabular}

Table 6: How is the correlation between $\mathrm{RC}$ and $\mathrm{HC}$ in Zanjan University STP firms.

in achieving their goals in today's ever changing environment is investigating and identifying the factors that enhance innovation. In this line, the relationship between organizational innovation and different variables has been tested by various studies in the literature. IC has been identified as one of the prerequisites and factors that affect organizational innovation.

IC in STPs is one of the important and effective factors that encourage innovation $[4,13]$. As an indicator of a range of knowledgebased assets, IC leads to the improvement of the competitive situation of an organization through increasing value for key stakeholders. Staff, managers, leaders, and supervisors all are considered as a STP's capital. This capital is recognized as a resource-based theory and it could also be considered a strategic source [19-24].

The main hypothesis of the study was confirmed. Therefore, it suggests that IC affects firms' innovation in a STP. Due to the intangible assets in the STP, development of these assets moves the firms towards the activities in which individuals are motivated to recognize and exploit entrepreneurial opportunities in order to reach higher innovation levels. Entrepreneurial activities ultimately lead to better innovative performance for the firms and STPs' firms can always be innovative and survive in the competitive environment. Hence, the findings of this study are in line with studies by Delgado [4], where they refer to IC as a potential source of competitive advantage for organizations which makes them grow and finally results in exploitation of entrepreneurial opportunities and facilitation of innovation in firms.

As the results of the study revealed, the main hypothesis as well as the first, second and fourth sub-hypotheses of the study were confirmed. In other words, it was positively and significantly confirmed that IC affects innovation, SC affects HC, SC affects RC, and finally RC affects innovation [25-30].

\section{Suggestions}

- It is recommended that knowledge-based firm managers enhance IC and hence innovation by creating and reinforcing a suitable culture within the organization.

- $\quad \mathrm{RC}$ alone does not guarantee constant innovation. STPs should also pay attention to $\mathrm{HC}$ to make ensure continued innovation.

- Managers can encourage their staff to acquire the most up-to-date knowledge and information through creating groups and knowledge teams.

\section{Refernces}

1. Morel L, Boly V (2006) New Product Development process (NPDP): Updating the identification stage Practices. International Journal of Product Development 3: 232-251.

2. AL-Dujaili M (2012) Influence of Intellectual Capital in the Organizational Innovation. International Journal of Innovation, Management and Technology 3: $128-135$.

3. Bontis N (2002) Intellectual Capital disclosure in Canadian corporations Journal of Human Costing and Accounting 3: 9-20.

4. Delgado $\mathrm{M}$ (2011) The role of intellectual capital assets on the radicalness of 
Citation: Maboudi M, Mobaraki MH, Khavandkar J, Esfandabadi HM (2015) The Effect of Intellectual Capital on Innovation: A Case Study of an Institute for Advanced Studies in Basic Sciences Located in the Science and Technology Park of Zanjan. J Entrepren Organiz Manag 4: 148. doi:10.4172/2169-026X.1000148

Page 5 of 5

innovation: direct and moderating effects. Autonomous University of Madrid.

5. Zerenler M, Hasiloglu SB, Sezgin M (2008) Intellectual Capital and Innovation Performance: Empirical Evidence in the Turkish Automotive Supplier. J Technol. Management Innovation 3.

6. Chen J (2004) Measuring intellectual capital: a new model and empirical study Journal of intellectual capital 5: 195-212.

7. Norma AJ (2006) The relationship between intellectual capital and new venture performance: an empirical investigation of the moderating role of environment. International Journal of Innovation and Technology Management 3.

8. Alam Tabriz J, Rajabi Fard I, Haji Baba Ali A (2010) Intellectual Capital Measurement, Disclosure, and Measurement Models. Industrial Research \& Training Center of Iran Publication, (1stedn), Winter.

9. Khavandkar J, Khavandkar E, Motaghi A (2011) The Intellectual Capital: Managing, Development Measurement Models (3rdedn). Industrial Research and Training Centre of Iran.

10. Edvinson L, Malone MS (1997) Intellectual Capital: Realizing Your Company's True Value by Finding its Hidden Brainpower. Harper Business, New York, NY.

11. Damanpour F, Walker RM, Avellaneda N (2009) Combinative effects of innovation types and organizational performance: a longitudinal study of service organizations. Journal of Management Studies 46: 650-675

12. Zeghal D, Maaloul A (2010) Analysing value added as an indicator of intellectua capital and its consequences on company performance. Journal of Intellectual Capital 11: 39-60.

13. Subramaniam M, Youndt MA (2012) The Influence of Intellectual Capital on the Types of Innovative Capabilities. The Academy of Management Journal 48: $450-463$

14. Edvinsoon $L$ (2000) Some Perspectives on Intangibles and Intellectual Capital 2000. Journal of Intellectual Capital 1: 12-16

15. Longo M (2007) A multidimensional measure of employees' intangible: A managerial implementation of the tool. Management Research News 30: 548569
16. Chang SL (2007) Valuing intellectual capital and firms performance: Modifying value added intellectual coefficient (vaic) in Taiwan IT industry.

17. Palmberg C (2004) The sources of innovations - looking beyond technological opportunities. Economics of Innovation and New Technology 13: 183-197.

18. Hult GTM, Hurley RF, Knight GA (2004) Innovativeness: Its antecedents and impact on business performance. Industrial Marketing Management 33: 429-438.

19. Allan A (2006) Innovation Management. Oxford University Press.

20. Alpkan L, Bulut C, Gunday G, Kilic K (2010) Organizational support for intrapreneurship and its interaction with human capital to enhance innovative performance. Management Decision 48: 755-775.

21. Castro GMD (2004) The Role of Corporate Reputation in Developing Relational Capital. Journal of Intellectual Capital 5: 575-585.

22. Diez J, Ochoa M , Prieto M, Santidrian A (2010) Intellectual capital and value creation in Spanish firms. Journal of Intellectual Capital 11: 348-367.

23. Kong E (2010) Innovation Processess in Social Enterprises: An IC Perspective. Journal of Intellectual Capital 11: 158-178.

24. Morel L, Boley V (2007) Innovation process evaluation: from self-assessmen to detailed technological audit. Management journal: 509-553.

25. Moreno AM, Casillas JC (2008) Entrepreneurial orientation and growth of SMEs: A causal model. Entrepreneurship Theory and Practice 32: 507-528.

26. Morris L (2006) Permanent Innovation. Oxford University Press 9: 25-38.

27. Nam K, Hee Lee N (2010) Typology of Service Innovation from ServiceDominant Logic Perspective. Journal of Universal Computer Science 16: 1761 1775

28. Ngah R, Ibrahim AR (2009) The Relationship of Intellectual Capital, Innovation and Organizational Performance: A Preliminary Study in Malaysian SMEs. International Journal of Management Innovation Systems 1: 1-12.

29. Pew Tan H, Plowman D, Hancock P (2008) The Evolving Research on Intellectual Capital. Journal of Intellectual Capital 9: 585-608.

30. Zaltman G, Duncan R, Holbek J (1973) Innovations and organizations Administrative Science Quarterly 19: 272-274 